\title{
MAGNUS STEVNS
}

1900-1949.

\section{Af VAGN RIISAGER.}

Magnus Stevns fødtes Sct. Hansdag 1900 som søn af højskoleforstanderens paa Kvissel Højskole i Vendsyssel. Selv skriver han herom i en mindeartikel om højskolen: „Sommerholdet, der kom efter, altsaa anno 1900 , duede ikke, det udgjordes af undertegnede. "Vel var den nyfødte dreng en maadelig højskoleelev, men han voksede op til et ægte barn af den danske folkehøjskole, en god discipel af dens aand.

Stevns uddannelse fik da ogsaa det noget krogede forløb, med capricieuse træskohop ud i det praktiske landbrug, som synes at kendetegne saa mange højskolebørns udvikling. Efter drengeaarene i det kære gamle Kvissel og barndomsundervisningen $\mathrm{i}$ landsbyskolen og hjemmet kom han paa Askov og Støvring højskoler som elev, medens han indimellem tjente for karl paa forskellige gaarde, indtil han omsider via Hostruphuse Ungdomsskole og Høng Studenterkursus naaede præliminær- og studenterexamen. Det var i 1924, og nu gik det løs med universitetsstudierne, skønt heller ikke her examens-ensrettet. Han studerede almindelig og sammenlignende litteraturhistorie hos Valdemar Vedel og Vilhelm Andersen og blev magister heri i 1930 med speciale i Kleist, men han havde ogsaa givet sig tid til at tage prøver i hebraisk og græsk og var en tid dybt inde $\mathrm{i}$ det teologiske studium, ligesom han havde været lærer baade paa Voldby og Borups højskoler. Nogle studierejser - til Berlin, Paris, Florentz og Rom havde han ogsaa faaet gjort, men efter at han i 1934 var blevet cand. mag. og aaret efter havde taget pædagogicum blev han fastboende i København som lærer ved Danmarks Lærerhøjskole (fra 1934 til sin død). I et par perioder var han desuden lærer ved Ingrid Jespersens Skole (42-43) og ved N. Zahles Seminarium $(47-48)$.

Det var ikke et almindeligt eentonigt liv, men et saare arbejdsomt, hvis hovedmaal trods alt aldrig tabtes af syne, der saa altfor brat afsluttedes den 30. marts 1949. - 
En discipel af højskolens aand var og blev han.

I en artikel om folkeviserne (1922) nævner han, at der paa Kvissel højskole ofte blev sunget folkeviser, og sikkert er det, hvor banalt det end kan lyde, at hans kærlighed til og forstaaelse af danske salmer saa vel som folkeviser blev sunget ind $\mathrm{i}$ hans drengehjerte $\mathrm{i}$ hjemmet og paa højskolen.

Typisk er det at lægge mærke til, hvorledes han, der var fortrolig med europæisk litteratur, stadigt tager de samme emner op til behandling; - bortset fra en enkelt artikel om folkeeventyr og Israels profeter og et par artikler om grundtvigske sange, er det folkeviserne og salmerne han altid skriver om.

Paa en anden maade er dette sikkert ogsaa højskolearv: han lærte at være vaagen og aaben for alt, samtidigt med at han maatte samle sig om det, hjertet havde faaet kært, thi kun paa det kunde man være klog. Naar han fik udgivet saa forholdsvis lidt, skyldtes det vel for en del, at han stillede saa næsten ufatteligt haarde krav til sine egne frembringelser, at han ikke kunde give noget fra sig, før det uangribelige og det fuldkomne var naaet i opnaaelig grad, men det skyldtes sikkert ogsaa, at han kun kunde producere om det, der for alvor havde fæstet rod i hans sind. Først naar afhandlingen - trods alle videnskabelige analyser - naturligt voksede frem af hans eget sind, først naar hver sætning som af sig selv groede frem, først saa blev han produktiv.

Senere lærte han videnskabelig metode, men den blev ham altid kun et redskab, altid kun et middel. Han hadede al gold æsteticisme, som han hadede al gold problemdebat og al livsfjern teologi. Hans mæle, der med al sin præcise klarhed er blidt og inderligt forstaaende, ofte med en lattermild ømhed, der næsten føles som kærtegn, kan ligefrem blive snertende skarpt, naar han omtaler disse aandens vildskud - og vistnok kun, naar han omtaler disse. Det er en livgivende fortolkning, han søger, det er et levende helhedsbillede han efterstræber, selv i specialanalysen af et enkelt ord (cf. Edda, 1940, pg. 300), det er digterens ord indblæst med alt det liv, det indeholder (og intet mere) han vil holde frem for læseren - og som han holder frem med samme ømme smil som var det en dunblød fugleunge $i$ hans hule haand.

Paa universitetet blev ogsaa hans arv fra højskolehjemmet yderligere slebet paa den maade, at han paavirkedes af Valdemar Vedels fine og noble personlighed, hans humanistiske, tolerante menneskelighed og hans ærlighed. Stevns blev aldrig en mand af brede ord og vide bevægelser, han var stille og beskedent ærlig, aldrig anderledes end at han fuldtud kunde staa ved det, en arv fra hjemmet vel, men ogsaa en lærdom fra universitetsaarene. Hans aandsform, der aldrig mistede 
barndomstidens og ungdomsaarenes præg, blev beslægtet med erasmianeren Valdemar Vedels.

Danskhed behøvede han ikke at lære af Vilh. Andersen, omend han modtog meget ogsaa af denne professor, det kunde han fra barnsben. Det var heller ikke først besættelsen, der lærte ham, at han kun kunde leve i den danske aandsform, thi den lærdom viser hele hans produktion fra hans første lille konventionelle digt fra 1920.

Han vidste ogsaa, at hans aandsform var kristen og aldrig kunde blive andet, men han havde faaet en bedsk afsmag for al teologi. Til gengæld var hans intuitive forstaaelse af kristendommen stærk og central - ikke for intet beskæftigede han sig først og sidst med salmer og hans forstaaelse af det guddommeligt hellige var barnlig og dyb. Atter her er det sanddruhed og ærlighed og angst for det uægte skabagtige, der er drivkraften. Han analyserer skriftstedet: „Salige er de fattige $\mathrm{i}$ aanden", og karakteriserer selvironisk beskedent sin udlægning som „en snakkesalig redegørelse for noget, som hverken præster eller degne eller nogen af vi andre bryder os om at maale værdier efter .."; men føjer til: „her er slet ikke tale om, hvad man vil maale værdier efter, det bliver virkelig en privatsag; men der er tale om slet og ret, hvad meningen med et velkendt udtryk er, og den mening kan man rent fornuftsmæssigt have behov af at finde, fordi det er urimeligt at sige, at en rose er gul, hvis den i virkeligheden er rød, urimeligt selv om det maaske behagede os bedst, om den var gul." (Elevforen. Kvissel Højsk. 1938). Han forstod, at „Israels tempel er stedet, hvor Gud bor, ikke hvor en eller anden præker, og hvor en eller anden kommer om søndagen, hvis der er tid, men stedet, hvor hver tomme jord er hellig ..." (smst. 1943), han kørte en dag eller anden „træt $i$ al verdens visdom og mest $i$ den ulidelige teologi“ og strøg „udenom diskussionerne til mesteren selv, der ikke er dialektiker, men blot vil tage barnet ind til sig“. Han vidste, at Gud, der "gavmildt sig forregner let", giver os, „hvad han kalder ret" (smst. 1936). -

Udfra et saadant livssyn og paa en saadan metode arbejdede han. Han kendte „den dybeste hemmelighed i al forskning: den at lade teksten tale for sig, lade den bære - ogsaa psykologisk - hvad den kan bære, men ikke paa nogen maade mere". Og hans evne til at indleve sig $\mathrm{i}$ et digt, hans evne til at sammenskue alle manuskriptvarianter, alle direkte og indirekte forbilleder og kilder, hans evne til at forstaa var dyb og nøjagtig, ligesom hans evne til udfra enkeltheden at se helheden.

Man synes sikkert, at det var saa altfor lidt, han naaede at faa udgivet, og man haaber med rette paa, at der i hans gemmer findes manuskripter til afhandlinger og foredrag, som er saavidt færdiggjorte, at de kan trykkes, alligevel: naar man overskuer hans artikler om Grundtvigs 


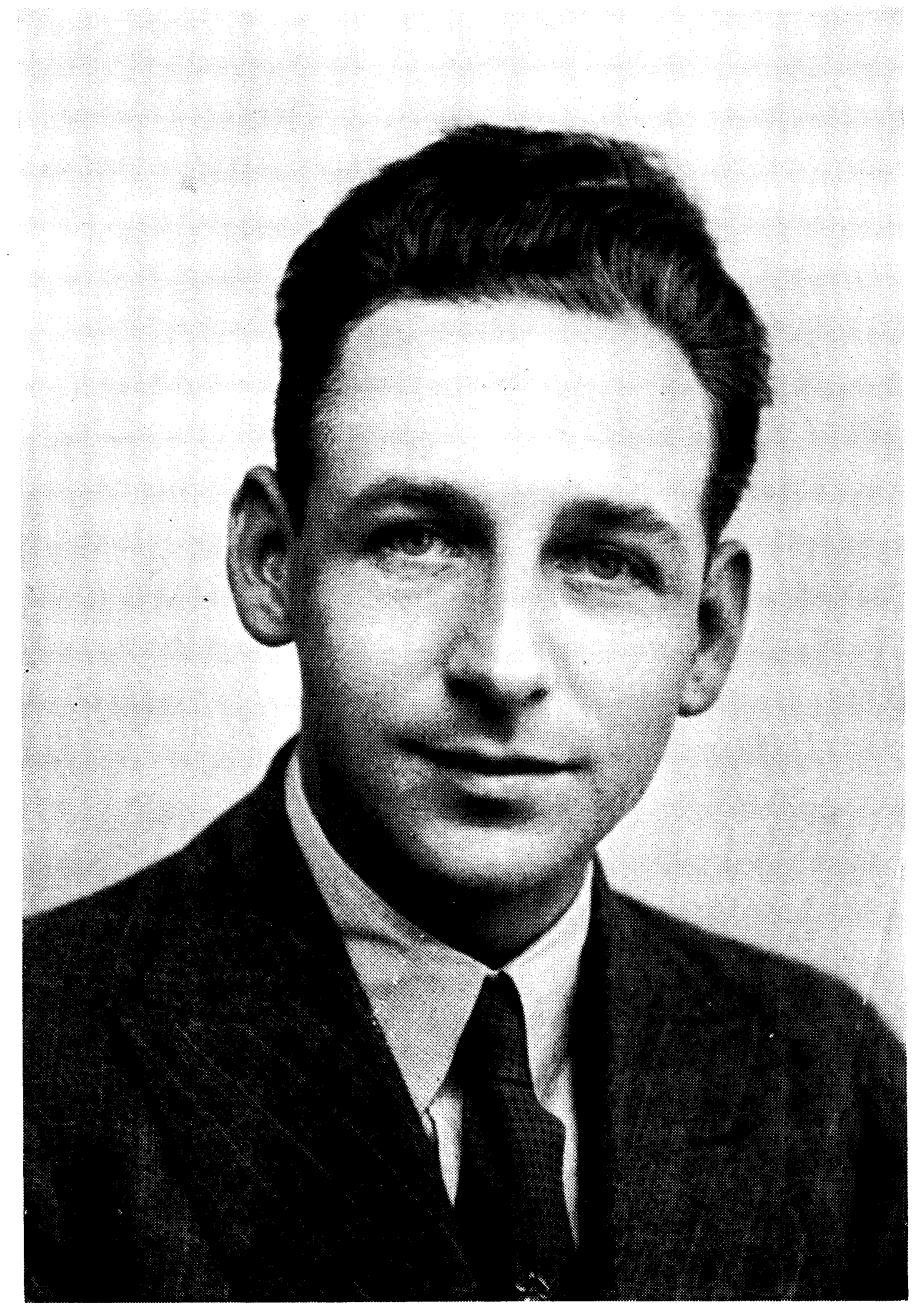

MAGNUS STEVNS 
salmer, er det hverken lidet eller betydningsløst, hvad han her har skabt, rent bortset fra at han ogsaa fik sagt noget aldeles væsentligt om Brorson (Brorsonartiklen „Advent“, Elevf. Kvissel Højsk. 1937). Man burde utvivlsomt udgive disse Grundtvig-afhandlinger $\mathrm{i}$ en bog, ikke blot fordi tidsskriftartikler er vanskelige at oplede, og ikke blot fordi saadanne artikler lettere glemmes, men fordi de samlet danner den bedste og paa sin vis mest udtømmende beskrivelse af Grundtvigs salmedigtning, som til dato er fremkommet.

Han belyser Grundtvigs arbejdsmetode, baade naar Grundtvig digter helt selvstændigt, og naar han "bearbejder" latinske salmer eller Kingos eller Brorsons. Han redegør for Gr.s naturbilleder og skriver den mærkelige afhandling „Kvinden i Grundtvigs Salmer“.

Spredte træk, spredte exempler, vil man sige. Ingenlunde! Vel knytter St. for det meste sine undersøgelser til bestemte, faa salmer, men hans undersøgelser er altid centrale, altid væsentlige, saaledes at det ikke blot bliver specialanalyser, men redegørelser for Grundtvigs aandstype og teologi og grundtvigsalmens karakter. Hans „Kvinden i Grundtvigs Digtning" er saaledes noget af det væsentligste, der er sagt om Gr.s kristologi, menneske- og menighedssyn. Eller man læse hans artikel her i hæftet om Grundtvig og Kingos Salmer og se, hvorledes det ikke er litteraturhistorie og æstetiske finesser, men helhedssyn og væsentligheder, der fremdrages.

Haderen af teologi var i virkeligheden en habil teolog; han, der afskyede æsteticisme, var en fin æstet, men hans undersøgelser blev hverken golde eller betydningsløse, fordi de byggede paa kærlig forstaaelse og inderlig indlevelse, og fordi de blev skrevet af det fine og følsomme menneske, der hed Magnus Stevns.

\section{B I B L I O G R A F I}

(Heri ikke medtaget avisartikler og anmeldelser).

Om salmer:

„Kingos sjette Morgensang“, Voldby Højsk. aarsskrift 1928.

„Lidt om danske Julesalmer", Elevforeningen Kvissel Højsk. 1931.

„Et Par Salmestrofer“ (Salmebog f. K. og Hj. no. 100, 2; 283, 1 og 366,1), Elevf. Kvissel Højsk., 1934.

„Kom i den sidste Nattevagt“. Studier for Sprog og Oldtidsforskning, no. 167 pg. 82 ff., 1934.

„Causeri og apologi“ (Om Ingemann), Elevf. Kvissel Højsk., 1936. "Advent“ (Brorsons salmedigtning), smst. 1937. 
„Noter og Nitter“ („Et Barn er født i Bethlehem“, samt om saligprisningen: „Salige er de fattige i aanden“), smst. 1938.

„Grundtvig-Manuskripter - Den sidste Nattevagt“, Danske Digtere ved arbejdet V, 1938. (Munksgaard).

„Fra Grundtvigs Salmeværksted“ („Op dog, Sion“ og „Det er saa yndigt at følges ad for to"), Danske Studier, 1938, pg. 1-17.

„Nogle Naturbilleder fra Grundtvigs Salmer", Edda 1940, pg. 266-300.

„Kvinden i Grundtvigs Salmer“, Gads Danske Magasin, 1941, pg. 436-451.

„Bemærkninger i Forbindelse med Helge Toldbergs „Moderne Grundtviglitteratur"." Dansk teol. Tidsskr. IX, 1946, pg. $191 \mathrm{f}$.

„Grundtvig og Kingos Salmer", Grundtvig-Studier, 1949, pg. 16-34.

Om folkeviser og folkeeventyr:

„Der var engang -“, Voldby Højsk. Aarsskrift 1926.

„Lidt om danske Folkeviser“, Elevf. Kvissel Højsk. 1922.

„Fæstemanden i Graven“, smst. 1935.

Varia:

„Modersmaal er vort Hjertesprog“, Elevf. Kvissel Højsk. 1939.

„Kvissel Folkehøjskole“, smst. 1939.

„Dine Fjender til Lands“, smst. 1940.

„Israels Profeter“, smst. 1943.

Vers:

„En Bøn“, Elevf. Kvissel Højsk., 1920.

„Pater Noster", smst., 1921.

„En Hilsen fra Kvissel“, smst., 1922.

„Andreas Buus“, Støvring Højsk. Aarsskrift 1924.

„Til Hjemmet i Kvissel“, Elevf. Kvissel Højsk., 1932.

\section{Udgivelser:}

„Vor nationale Sang“ (forord af Hans Brix), Hasselbalchs kulturbibliotek, bd. 1, 1941.

Johs. Ewald : „Levned og Meninger“, smst., 1941.

Blichers Noveller, Det danske Forlag, 1947.

Paludan-Müller : „Abels Død“, smst., 1948.

Desuden forestod han fra 1944 til sin død arbejdet med Gr.s haandskrifter til den nye udgave af Sangværket (Det grundtvigske Salmefond og De danske Andelsforeninger). 